\title{
Groundwater circulation and hydrogeochemical evolution in Nomhon of Qaidam Basin, northwest China
}

\author{
Yong XiaO ${ }^{1}$, Jingli ShaO $^{1,3, *}$, Yali Cui ${ }^{1},{\text { Ge } \text { Zhang }^{2,3} \text { and Qiulan Zhang }}^{1}$ \\ ${ }^{1}$ School of Water Resources and Environment, China University of Geosciences, Beijing 100083, China. \\ ${ }^{2}$ Xi'an Center of Geological Survey, China Geological Survey, Xi'an 710054, China. \\ ${ }^{3}$ Key Laboratory of Groundwater and Ecology in Arid and Semi-arid Regions, China Geological Survey, \\ Xi'an 710054, China. \\ *Corresponding author.e-mail: jshao@cugb.edu.cn
}

In this study, analysis of hydrogeological conditions, as well as hydrochemistry and isotopic tools were used to get an insight into the processes controlling mineralization, recharge conditions, and flow pattern of groundwater in a typical arid alluvial-lacustrine plain in Qaidam Basin, northwest China. Analysis of the dissolved constituents reveals that groundwater evolves from fresh water (TDS=300-1000 mg/l) to saline water (TDS $\geq 5000 \mathrm{mg} / \mathrm{l}$ ) along the flow paths, with the water type transiting from $\mathrm{HCO}_{3} \cdot \mathrm{Cl}_{-}$ $\mathrm{Na} \cdot \mathrm{Mg}$ to $\mathrm{HCO}_{3} \cdot \mathrm{Cl}-\mathrm{Na}$, and eventually to $\mathrm{Cl}-\mathrm{Na}$. Groundwater chemical evolution is mainly controlled by water-rock interaction and the evaporation-crystallization process. Deuterium and oxygen-18 isotopes in groundwater samples indicate that the recharge of groundwater is happened by meteoric water and glacier melt-water in the Kunlun Mountains, and in three different recharge conditions. Groundwater ages, estimated by the radiogenic $\left({ }^{3} \mathrm{H}\right.$ and $\left.{ }^{14} \mathrm{C}\right)$ isotope data, range from present to Holocene $(\sim 28 \mathrm{ka})$. Based on groundwater residence time, hydrogeochemical characteristics, field investigation, and geological structure distribution, a conceptual groundwater flow pattern affected by uplift structure is proposed, indicating that shallow phreatic water is blocked by the uplift structure and the flow direction is turned to the northwest, while high pressure artesian water is formed in the confined aquifers at the axis of the uplift structure.

\section{Introduction}

Qaidam Basin is a hyper-arid region located in northwest China (Jiao et al. 2015). Groundwater plays a crucial role in irrigation and drinking water supplies, industrial production and ecology maintenance. Due to the rich mineral resources, oil and natural gas reservoirs, Qaidam Basin was granted as a state test of cyclic economy (Tan et al. 2009), which led to higher demands for water. The shortage of water will be a threat to sustainable development and ecology of the basin. Therefore, a full understanding of groundwater circulation and evolution in this region is of strategic importance (Stadler et al. 2010; Herrera et al. 2016).

Much research has been performed on the material sources of the salt lake, ecology evolution, groundwater storage and hydrochemical characteristics, etc., in Qaidam Basin, and made progress in some aspects (Lowenstein and Risacher 2009; Ma et al. 2012; Wei et al. 2014; Jiao et al. 2015; Lu and Jin 2015; Ye et al. 2015; Zhang et al. 2015; Jin et al. 2016). For example, Lu and Jin (2015) and Jin et al. (2016) investigated the evolution of ecology at different scales and concluded that, with the increase of precipitation and rising of groundwater

Keywords. Hydrochemistry; groundwater circulation; isotopes; water-rock interaction; Qaidam Basin. 
level, ecology had the tendency to improve both at local and basin scales in recent years; Jiao et al. (2015) performed a Gravity Recovery and Climate Experiment (GRACE) study on the groundwater storage at basin scale and found that groundwater storage of the basin was increased between 2003 and 2012, which would improve the ecology and environment of Qaidam Basin; Ye et al. (2015) investigated the hydrochemical characteristics and sources of brines in the Gasikule salt lake, northwestern Qaidam Basin, and they drew a conclusion that the material sources of the salt lake included stream water, leaching of Pliocene salt-bearing host rocks, and the $\mathrm{Ca}-\mathrm{Cl}$ type deep water; Ma et al. (2012) preformed an isotope study in the Glomud subdrainage basin, and concluded that groundwater was the main source of salt lakes. However, knowledge on origin, recharge condition, transit time, flow regime and evolution of groundwater of the basin are still poorly understood or totally unknown (Tan et al. 2009).

With the improved analytical techniques for stable environmental isotopes of water, radiogenic isotopes, hydrogeological information can easily be deciphered. Generally, stable isotopes of oxygen and hydrogen in water are used to identify the origin of groundwater and work as space tracers (Van Geldern et al. 2014; Khalil et al. 2015). The radiogenic isotope ${ }^{3} \mathrm{H}$, which have a known continuous varying concentrations in the atmosphere after the bomb testing in 1952-1962, is used for the estimation of recent groundwater age (Zhai et al. 2013). While ${ }^{14} \mathrm{C}$ with half-life of 5730 a, works as age tracer of 'ancient' groundwater recharged before bomb testing (Geyh 2005; Hoque and Burgess 2012). The combination of these environmental isotopes, can provide valuable insight into regime and movement of groundwater, and has been widely used to determine groundwater origin, recharge condition, flow paths and residence times in aquifer (Tirumalesh et al. 2007; Van Geldern et al. 2014; Wang et al. 2015). These methods can contribute enormously to our understanding of groundwater circulation and evolution at local, regional and basin scales.

In addition, hydrochemistry has made significant contributions to the understanding of groundwater evolution (Li et al. 2008; Dar et al. 2014). Groundwater carries chemical signatures of recharge water and interaction with minerals and sediments forming aquifers along the flow paths as well as anthropogenic activities (Yangui et al. 2011; Monjerezi et al. 2012; Voutsis et al. 2015). The processes controlling hydrochemistry can be revealed by ionic ratio plot and saturation state simulation using Phreeqc interactive program (Reddy and Kumar 2010; Bouzourra et al. 2014).
The principal aims of the present study are to:

- understand the causes and mechanisms controlling the groundwater chemistry;

- determine the origin and recharge conditions of groundwater;

- constrain the relative residence time of groundwater in aquifers;

- ultimately establish the groundwater flow pattern in a typical arid alluvial-lacustrine plain of Qaidam Basin.

\section{Study area}

The study area is located in southeastern Qaidam Basin, northwest China (figure 1). It comprises the Nomhon alluvial fan with elevations ranging from 2720 to $3000 \mathrm{~m}$, and a gently-sloping lacustrine plain varying from 2700 to $2720 \mathrm{~m}$. Nomhon River, the sixth largest river in Qaidam Basin, runs through the alluvial-lacustrine plain from southern mountainous area to northern lower basin. The main water sources feeding Nomhon River are meteoric water and glacier melt-water in the Kunlun Mountains. Tiangeli River, the major spring-fed river, is located in the northwest of Nomhon alluvial fan. The study area is one of the most extremely arid areas in Qaidam Basin with high annual evaporation $(>2600 \mathrm{~mm})$ and rare annual precipitation $(<50 \mathrm{~mm})$. Characterized by large temporal and spatial variations, $68 \%$ of rainfall occurs from June to August and concentrates in the southern piedmont area. The annual average temperature is $4.5^{\circ} \mathrm{C}$, with highest in July $\left(17^{\circ} \mathrm{C}\right)$ and lowest in January $\left(-10^{\circ} \mathrm{C}\right)$.

The main stratums outcropping in the area range from Devonian up to the Quaternary period. The former Quaternary deposits are mainly found in southern mountainous area. Whereas the alluvial fan and lacustrine plain are characterized by outcropping of Quaternary deposits with a thickness of several hundred meters. The regional Quaternary aquifers vary from a zone of single unconfined gravel and pebbles in the upper alluvial fan to a multi-layered zone comprising sand and clay in the lower basin, resulting groundwater occurring under unconfined to semi-confined and then to confined conditions. The Quaternary aquifers are strongly affected by tectonic activities along the edge of Kunlun Mountains, resulting some faults and folds, especially the uplift structure found at the front of the alluvial fan (figure 10).

Based on the topography and hydrogeological conditions, the study area was further divided into five zones (figure 1). Zone 1 is located in the axis of the alluvial fan and is the groundwater recharge zone with unconfined single-layer aquifer. Located in 


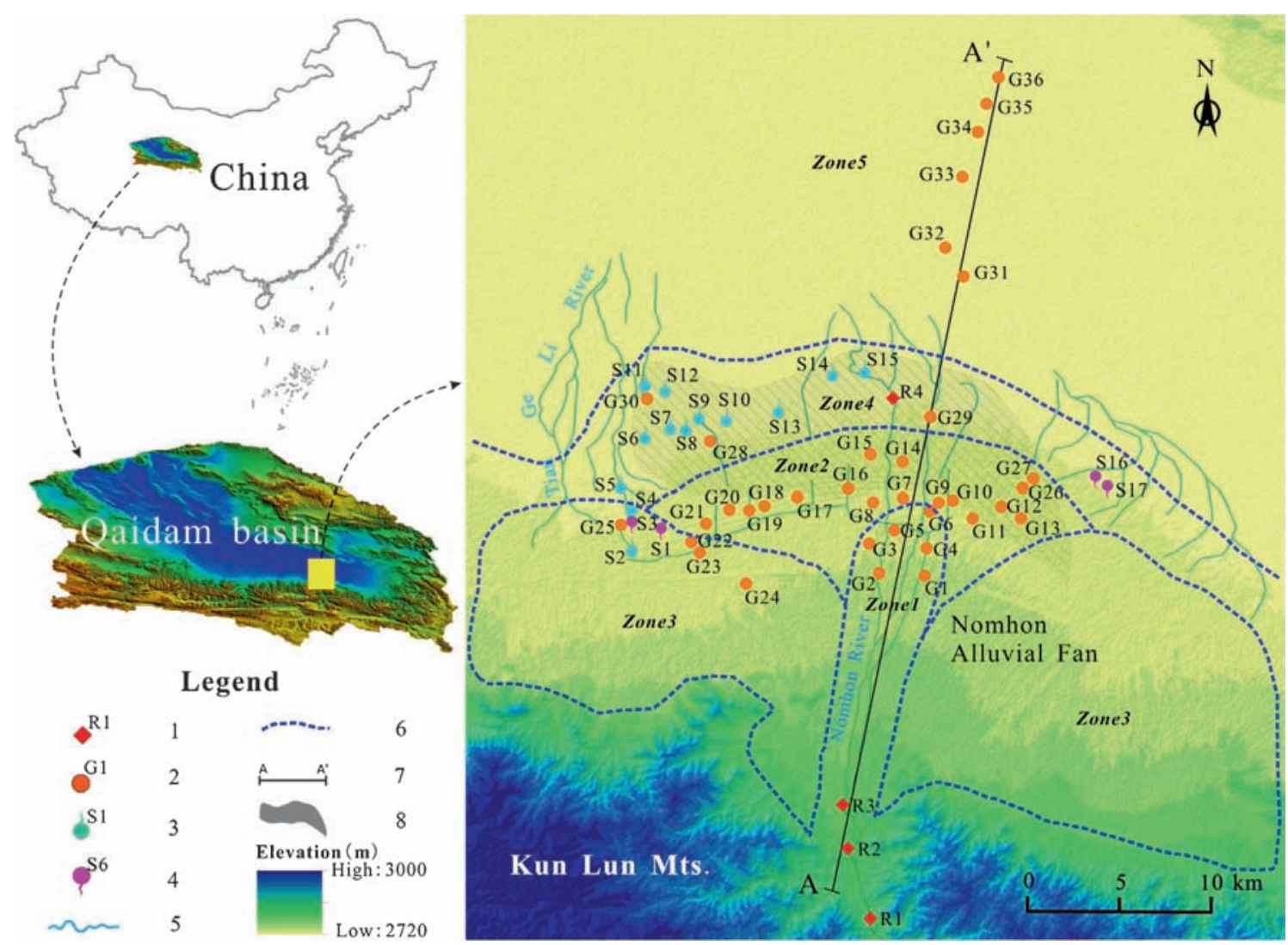

Figure 1. Location of the study area and sampling sites. 1. River water sample, 2. groundwater sample, 3 . ascending spring sample, 4. descending spring sample, 5. rivers, 6. boundary lines of zones, 7 . profile, and 8. uplift structure.

the front of the alluvial fan, Zone 2 is the groundwater runoff zone and the aquifer changes from unconfined to semi-confined. Zone 3 is the wings of the alluvial fan and has relatively poorer permeability compared with Zone 1 . Zone 4 is the overflow area with confined aquifer. A lot of springs and spring-fed rivers are distributed in Zone 4 . Zone 5 , located in the lower basin, is the groundwater discharge area with multi-confined aquifers. The lacustrine sediments in Zone 5 are composed of alternate layers of sand and clay with poor groundwater runoff condition. According to the traditional points, the flow direction of groundwater is from south to north. The groundwater system is naturally recharged by lateral flow in the edge of Kunlun Mountains and river seepage in Zone 1. Groundwater discharge is mostly via evaporation in Zone 5 and exploitation in Zone 3.

\section{Sampling and analytical methods}

A total of 67 groundwater samples and four river water samples were collected for chemistry and isotopic analysis in July-September 2013. The sampled sites distribute throughout the alluvial fan and lacustrine plain (figure 1). River water samples were collected along the Nomhon River. Groundwater samples were collected from springs and boreholes. Most boreholes in the alluvial fan were drilled typically to depth between 30 and $150 \mathrm{~m}$, revealing the phreatic aquifer or semi-confined aquifer. While the depths of boreholes in the northern lacustrine plain range from 60 to $400 \mathrm{~m}$, revealing both shallow phreatic aquifer and deep-confined aquifer. Two boreholes (G29 and G32) in the northern lacustrine plain are multiple-layered boreholes, with 10 and 11 screened layers, respectively. Samples and their information relevant are shown in table 1. Groundwater in non-artesian boreholes were pumped for half-an-hour to remove the stagnant water before sampling. Parameters such as electrical conductivity (EC), $\mathrm{pH}$ and water temperature ( $\mathrm{T}$ ) were measured using an in-situ multi-parameter instrument (Multi 350i/SET). The sampled methods for major ion analyses and isotopic measurements were described by Huang et al. (2016) and Chen et al. (2011), respectively.

All samples were stored in portable coolers containing ice packs and transferred to the Laboratory of Groundwater Sciences and Engineering in the Institute of Hydrogeology and Environmental Geology, Chinese Academy of Geological Sciences for analysis. Major cation $\left(\mathrm{K}^{+}, \mathrm{Na}^{+}, \mathrm{Ca}^{2+}, \mathrm{Mg}^{2+}\right)$ analyses were performed by inductively-coupled plasma-mass spectrometry (Agilent 7500ce ICP-MS, 


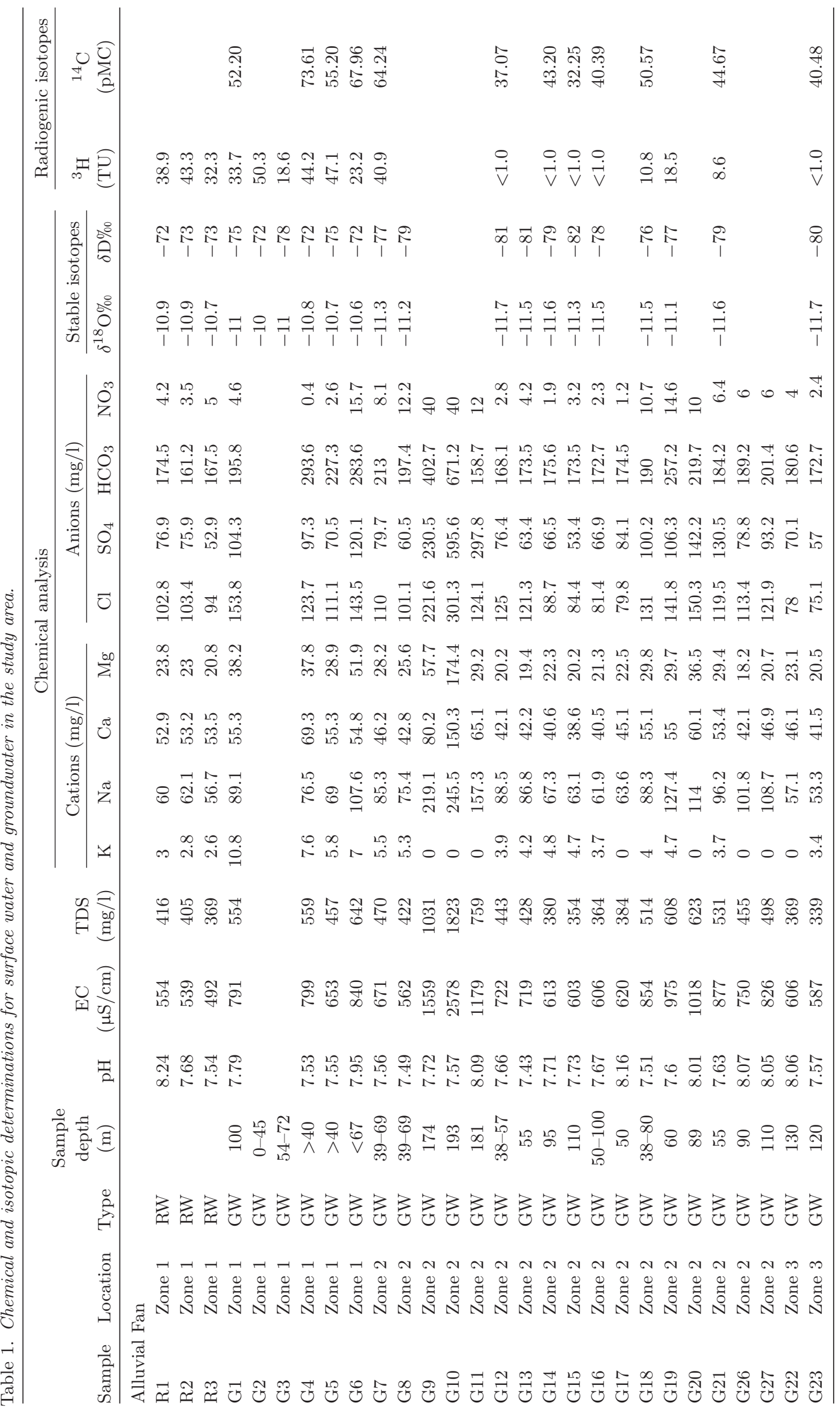




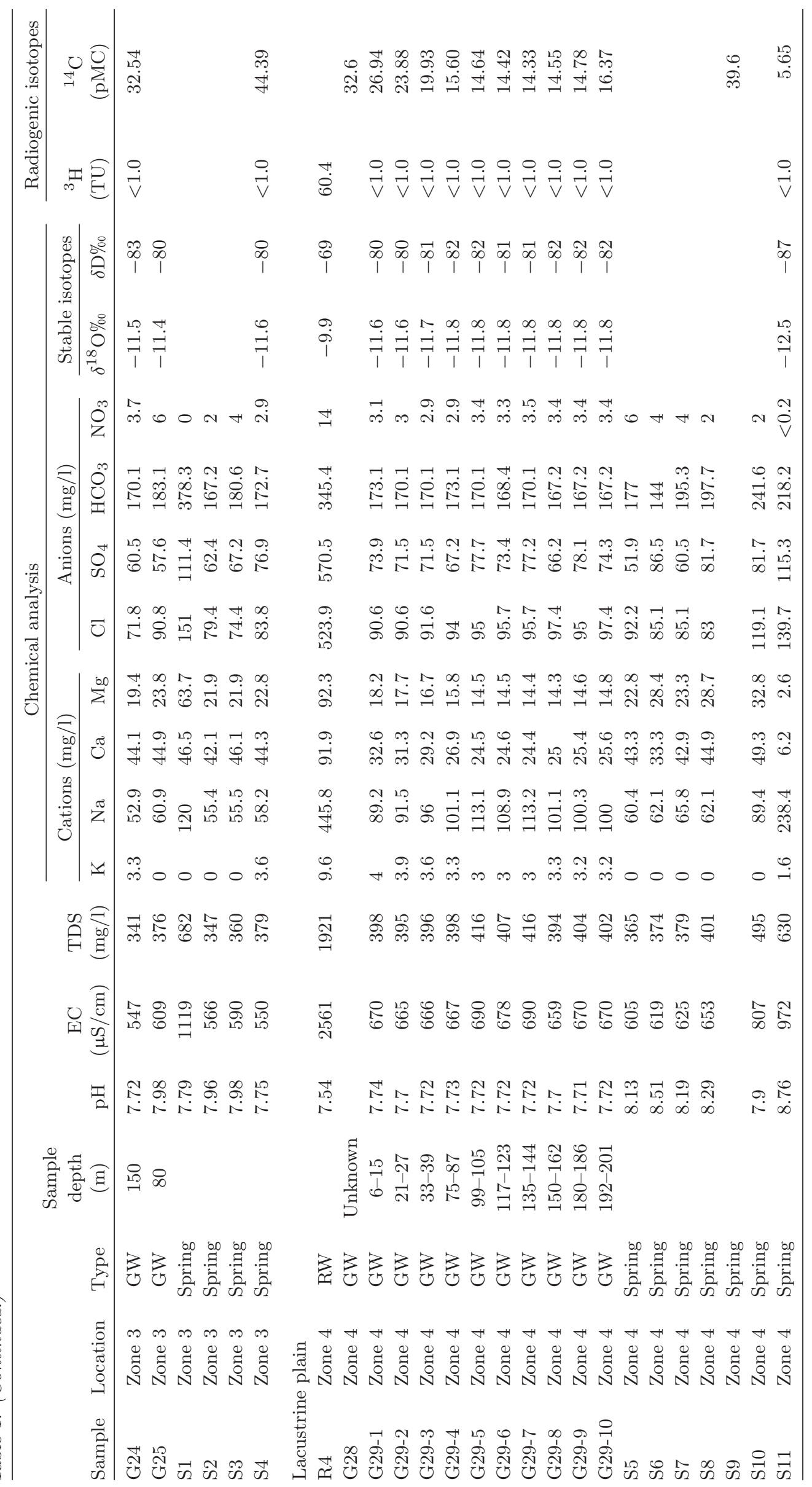




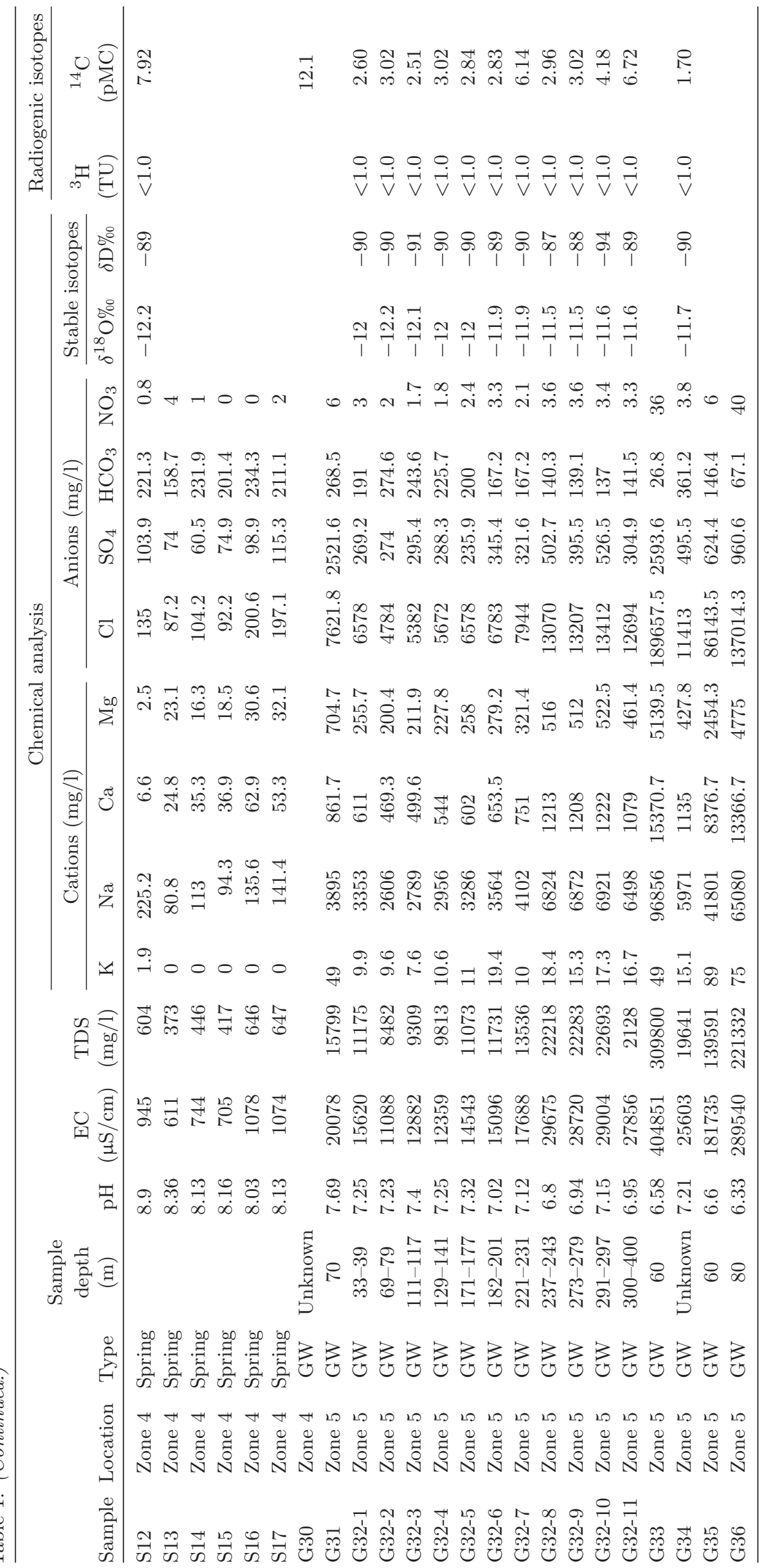


Tokyo, Japan). Analyses for total concentration of $\mathrm{Cl}^{-}, \mathrm{SO}_{4}^{2-}$ and $\mathrm{NO}_{3}^{-}$were carried out by spectrophotometry (Perkin-Elmer Lambda 35, Waltham, MA, USA). $\mathrm{HCO}_{3}^{-}$and total dissolved solids (TDS) were measured by acid-base titration and gravimetric analysis, respectively (Huang et al. 2016). Cation-anion balances of all samples are with $<5 \%$ difference. Stable isotope ratios $\left({ }^{2} \mathrm{H} /{ }^{1} \mathrm{H}\right.$ and ${ }^{18} \mathrm{O} /{ }^{16} \mathrm{O}$ ) were determined by isotope ratio mass spectrometry using a Finnigan MAT 253 and reported to be relative to VSMOW with analytical errors of $\pm 1.0 \%$ and $\pm 0.2 \%$, respectively. Tritium content was analyzed using electrolytic enrichment and liquid scintillation technique, and expressed in Tritium Unite (TU). Precision of tritium results are equal to \pm 0.3 TU. Activity of ${ }^{14} \mathrm{C}$ was determined by accelerator mass spectrometry. Analytical results were expressed as a percentage of modern carbon (pMC) with a standard deviation of 0.7 to 1.0 pMC. The results are presented in table 1.

\section{Results and discussion}

\subsection{Hydrochemistry}

\subsubsection{Spatial distribution of groundwater chemistry}

As shown in table 1 , the $\mathrm{pH}$ values of groundwater and spring water in the study area vary from 6.33 to 8.76 , lying in the range of slightly acidic to slightly alkaline. The $\mathrm{pH}$ values were observed to decrease gradually with the increase of groundwater cycle depth and distance of water flow path. The TDS and EC values are both in a relatively wide range (0.554-309.8 g/l for TDS, $791-4.05 \times$ $10^{5} \mu \mathrm{S} / \mathrm{cm}$ for EC). Both TDS and EC values showed an increasing trend from the mountain pass to the lower basin, indicating that groundwater gradually accumulated chemistry compositions and evaluated from fresh water to saline water along the groundwater flow path.

The Piper diagram (figure 2) showed that there are three chemical types of groundwater in the study area: $\mathrm{HCO}_{3}-\mathrm{Cl}-\mathrm{Mg}-\mathrm{Na}, \mathrm{HCO}_{3}-\mathrm{Cl}-\mathrm{Na}$ and $\mathrm{Cl}-\mathrm{Na}$ types. The spatial distribution of the groundwater chemical type showed that groundwater in the alluvial fan was mainly $\mathrm{HCO}_{3}-\mathrm{Cl}-\mathrm{Mg}-\mathrm{Na}$ type, which coincided with the river water in upper alluvial fan, reflecting the characteristic of the recharge area; groundwater in the overflow area was mainly $\mathrm{HCO}_{3}-\mathrm{Cl}-\mathrm{Na}$ type, showing the characteristic of runoff area; and in the lower basin was dominantly, $\mathrm{Cl}-\mathrm{Na}$ type with extremely high TDS values, presenting the characteristic of discharge area.

\subsubsection{Mechanisms controlling groundwater chemistry}

Groundwater chemistry is affected by many factors such as original composition of recharge water, rock type, residence time in the host rock, and other characteristics of the groundwater flow path (Redwan and Moneim 2015). The relation between major ions could reveal the groundwater chemical compositions origin and hydrochemistry processes in the evolution of groundwater (Wang et al. 2013).

Relations of major ions were presented in figure 3. Most of the samples, especially those in the alluvial fan, situated along the halite and gypsum (anhydrite) dissolution line (figure 3a, b), but many of them plotted away from the calcite (aragonite) and dolomite dissolution line (figure 3c, d), suggest that halite, gypsum and anhydrite dissolution can be the important origin of groundwater chemical compositions, while the contributions of calcite, aragonite and dolomite dissolution can be very limited or affected by other factors. To further examine the contribution of these minerals, groundwater saturation state was computed using PHREEQC program. The results showed that most of groundwater samples were in an undersaturation state $(\mathrm{SI}<0)$ with respect to halite, gypsum and anhydrite minerals (figure $4 \mathrm{a}, \mathrm{b}, \mathrm{c}$ ), but in an oversaturation state (SI $>0$ ) with respect to calcite, aragonite and dolomite (figure 4d, e, f), indicating that groundwater chemical composition was contributed by halite, gypsum and anhydrite dissolution, not calcite, aragonite and dolomite dissolution.

Figure 3(a, b) also showed that sample points plotted slightly away the halite and gypsum (anhydrite) dissolution line, suggesting that there may exist some other hydrogeochemical processes which affected the chemical composition of groundwater. Points sampled in alluvial fan and overflow area situated slightly above the halite dissolution line (figure 3a), and below the calcite dissolution line (figure 3c), showing a trend of increase of $\mathrm{Na}^{+}$content and decrease of $\mathrm{Ca}^{2+}$ content along the water flow path. This indicated that the cation exchange (R1), where $\mathrm{Ca}^{2+}$ was absorbed on the clay and $\mathrm{Na}^{+}$was released into the water, contributed the chemical compositions of groundwater in these areas (Fisher and Iii 1997). While points sampled from lower basin were observed in an opposite situation. Most plots situated below the halite dissolution line (figure 3a) and above the gypsum, calcite and dolomite dissolution line (figure $3 \mathrm{~b}, \mathrm{c}, \mathrm{d}$ ). This showed a trend of increase of $\mathrm{Ca}^{2+}$ content and decrease of $\mathrm{Na}^{+}$content, indicating a reverse cation exchange (R2), was one of the hydrogeochemistry process in the area (Appelo and Postma 2005). The relation of $\left(\mathrm{Ca}^{2+}+\mathrm{Mg}^{2+}\right)-\left(\mathrm{SO}_{4}^{2-}+\mathrm{HCO}_{3}^{-}\right)$vs. $\left(\mathrm{Na}^{+}-\right.$ $\mathrm{Cl}^{-}$) (figure 5) confirmed the existence of these two ionic exchange processes (Farid et al. 2015). Additionally, $\mathrm{SO}_{4}^{2-}$ bacterial reduction (R3) was also the reason leading the molar ratios of $\mathrm{Ca}^{2+} / \mathrm{SO}_{4}^{2-}$ for the groundwater samples in the lower basin above 1 (Farid et al. 2015), and this was confirmed by 


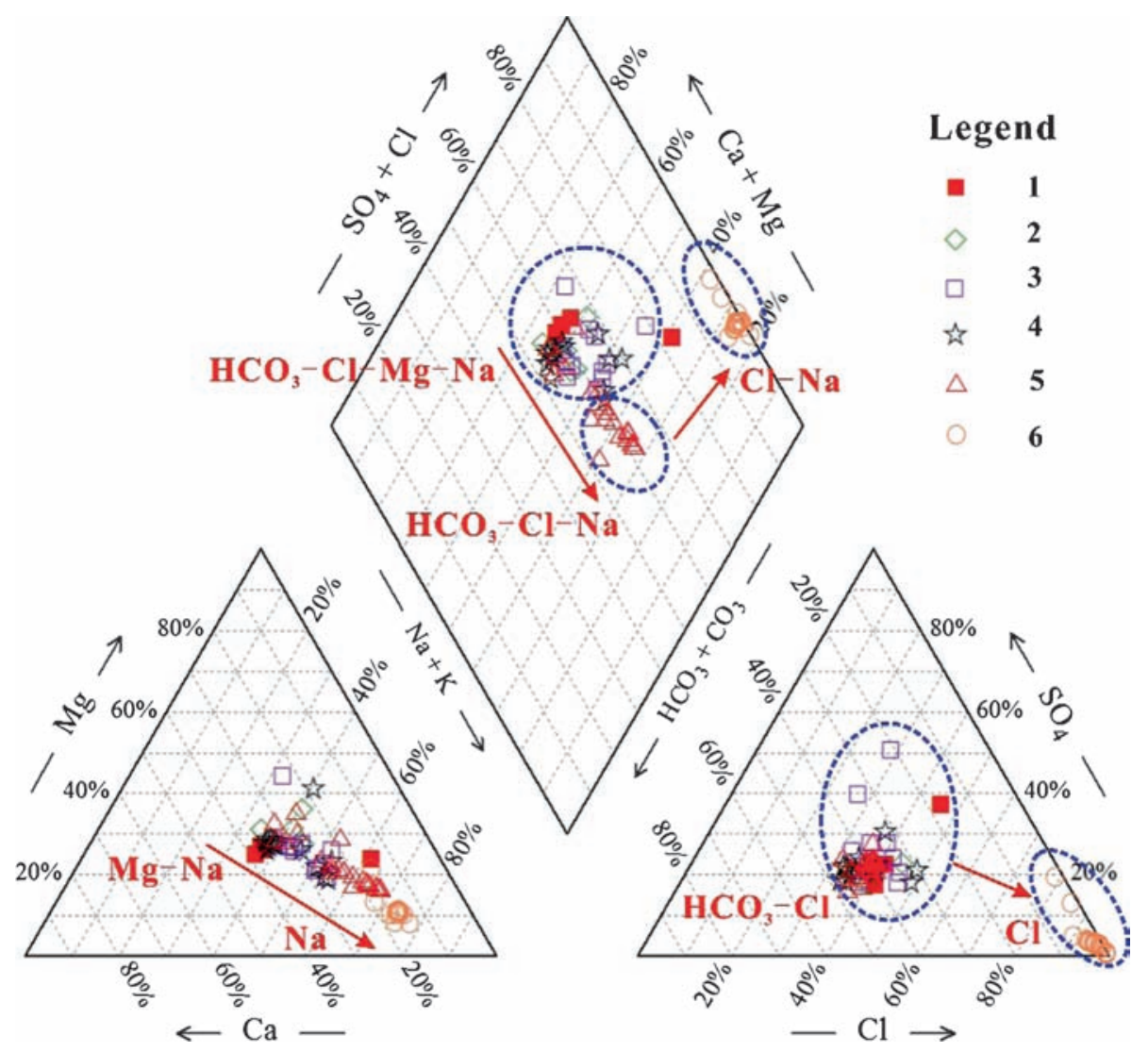

Figure 2. Piper diagram of all groundwater and surface water samples. 1. River water samples, 2. GW samples in Zone 1, 3. GW samples in Zone 2, 4. GW samples in Zone 3, 5. GW samples in Zone 4, and 6. GW samples in Zone 5.

the absence of $\mathrm{SO}_{4}$ type groundwater in the study area.

$$
\begin{aligned}
& \mathrm{Ca}^{2+}+2 \mathrm{Na}-\mathrm{X} \rightarrow \mathrm{Ca}-\mathrm{X}_{2}+2 \mathrm{Na}^{+} \\
& 2 \mathrm{Na}^{+}+\mathrm{Ca}-\mathrm{X}_{2} \rightarrow 2 \mathrm{Na}-\mathrm{X}+\mathrm{Ca}^{2+} \\
& \mathrm{SO}_{4}^{2-}+2 \times \frac{1}{n}\left(\mathrm{CH}_{2} \mathrm{O}\right)_{n} \rightarrow \mathrm{H}_{2} \mathrm{~S}+2 \mathrm{HCO}_{3}^{-}
\end{aligned}
$$

Gibbs diagrams (figure 6) were introduced to assess the influence of evaporation, rock and precipitation on groundwater geochemistry. The sampling points of groundwater spread from rock domain towards the evaporation one, indicating that the chemistry of groundwater was dominantly controlled by water-rock interaction and evaporation-crystallization. Figure 6 also showed the groundwater points sampled in alluvial fan and overflow area plotted in the rock domain, while those sampled in lower basin plotted in the evaporation domain, indicating the chemistry of groundwater in the alluvial fan and the overflow area was mainly controlled by water-rock interaction and that in the lower basin was dominantly influenced by evaporation-crystallization (Yu et al. 2013; Redwan and Moneim 2015). Points sampled from deep aquifer in the lower basin also situated in the evaporation domain, suggesting that deep groundwater in lower basin was influenced by evaporation in the geologic history. No point plotted in the transition domain between rock domain and evaporation domain (figure 6), suggesting that the influence of evaporation on groundwater chemistry was very limited in the flow path from alluvial fan to lacustrine plain.

\subsection{Isotope data}

\subsubsection{Origin and recharge characteristics of groundwater}

Stable oxygen and hydrogen isotope form a powerful diagnostic tool to examine the water provenance and recharge characteristics of groundwater. As seen in table 1 , the compositions of oxygen and hydrogen isotopes represented that the river water in the upper alluvial fan (R1, R2, R3) ranged from $-10.9 \%$ to $-10.7 \%$ and from $-73 \%$ to $-72 \%$, respectively, and that in the overflow zone (R4) was $-9.9 \%$ and $-69 \%$ for $\delta^{18} \mathrm{O}$ and $\delta^{2} \mathrm{H}$, respectively. This suggests that river water was affected by evaporation, as a result, the $\delta^{18} \mathrm{O}$ and $\delta^{2} \mathrm{H}$ values became more enriched along the flow path. This was also confirmed by the variation of TDS and EC values, which were in the range of 369$416 \mathrm{mg} / \mathrm{L}$ and $492-554 \mu \mathrm{S} / \mathrm{cm}$ in the upper alluvial fan (R1, R2, R3) and increased to $1921 \mathrm{mg} / \mathrm{L}$ and 

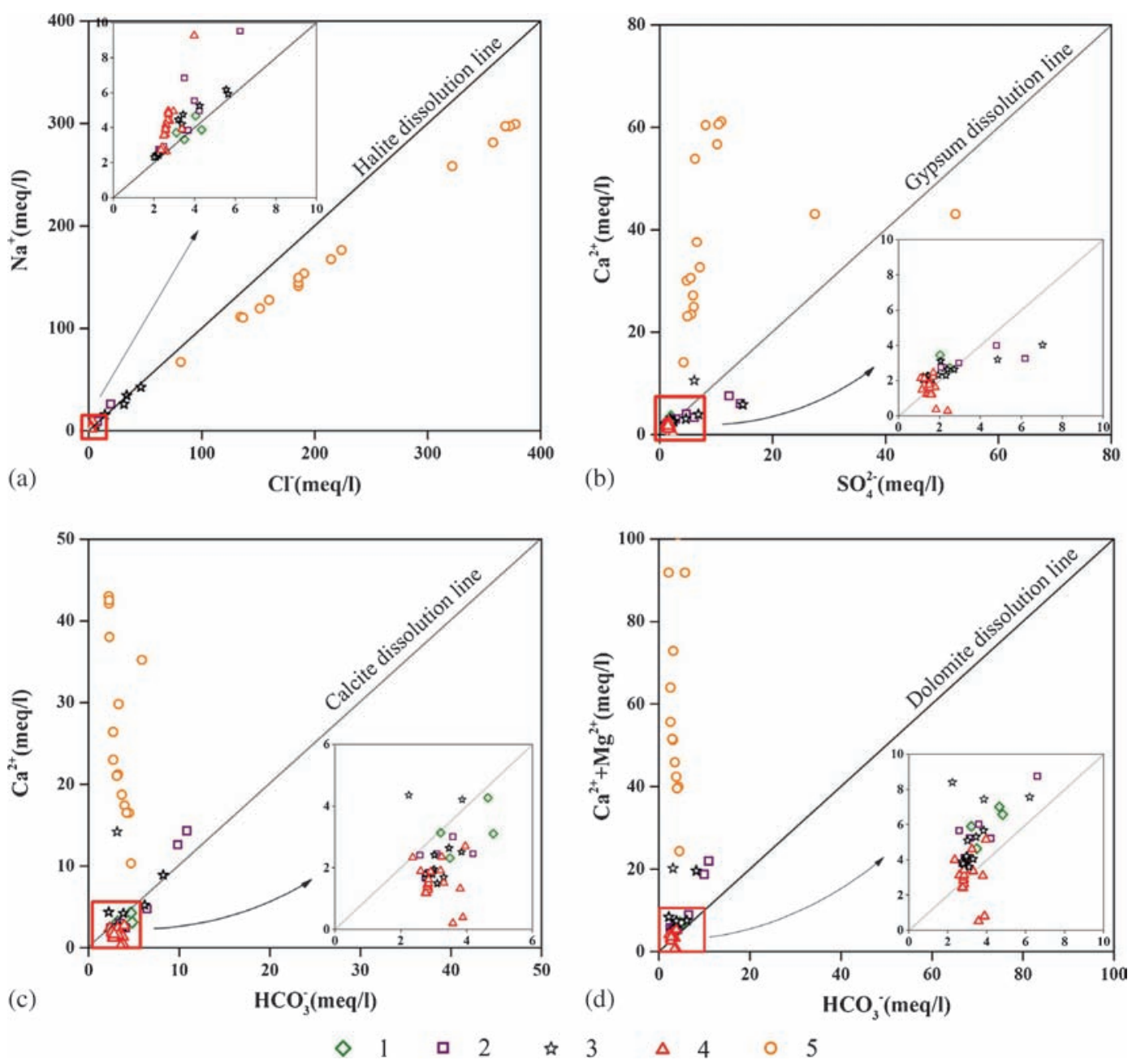

Figure 3. Bivariate plot of different ions showing the correlation of major ions to discriminate the chemical processes in the aquifer. 1. GW samples in Zone 1, 2. GW samples in Zone 2, 3. GW samples in ZOne 3, 4. GW samples in Zone 4, and 5. GW samples Zone 5.

$2561 \mu \mathrm{S} / \mathrm{cm}$ in the overflow area (R4), respectively. The $\delta^{18} \mathrm{O}$ and $\delta^{2} \mathrm{H}$ values of groundwater varied between $-11.8 \%$ and $-10.0 \%$ and from $-83 \%$ to $-72 \%$, respectively. The isotopic composition of both river water and groundwater mainly plotted along the local meteoric water line (LMWL) which was established by Wang (2008), indicate their meteoric origin. Due to very rare precipitation $(<50 \mathrm{~mm}$ per year) and uneven tempo-spatial distribution, the local precipitation recharge amount was very limited and can be ignored. Groundwater in the basin originated mainly from the glacier melt-water and meteoric water in the Kunlun Mountains, and was recharged through the seepage of Nomhon River in the alluvial fan and the bedrock lateral flow along the edge of Kunlun Mountains.

The isotopic composition of groundwater showed a depleted trend along the water flow path, and could be clustered into three groups (figure 7). Samples in Group A with the most enriched isotopic composition were sampled from the phreatic aquifer in Zone 1, and with the similar isotopic composition to the river water (R1, R2, R3) in upper alluvial fan. This indicated that groundwater in Zone 1 was recharged directly by the modern water of Nomhon River with a rapid water alternate rate. While samples in Group C with the most depleted isotopic composition were sampled from both phreatic and confined aquifers in lower basin, and presented obvious depletion of isotopic compositions compared to the modern river water $(\mathrm{R} 1, \mathrm{R} 2, \mathrm{R} 3)$. This suggested that groundwater in the lower basin was recharged by ancient water under a colder and wetter climatic condition with respect to the modern recharge condition (Utting et al. 2013). The isotopic composition of Group B presented a gradual depleted trend varying from Group A to Group C with the increase of sampled depth and distance of water flow path. This indicated that groundwater in the front and wings of Nomhon alluvial fan as well as overflow area was recharged in the period of climate changing from ancient cold and wet condition to the modern hot and dry condition. 

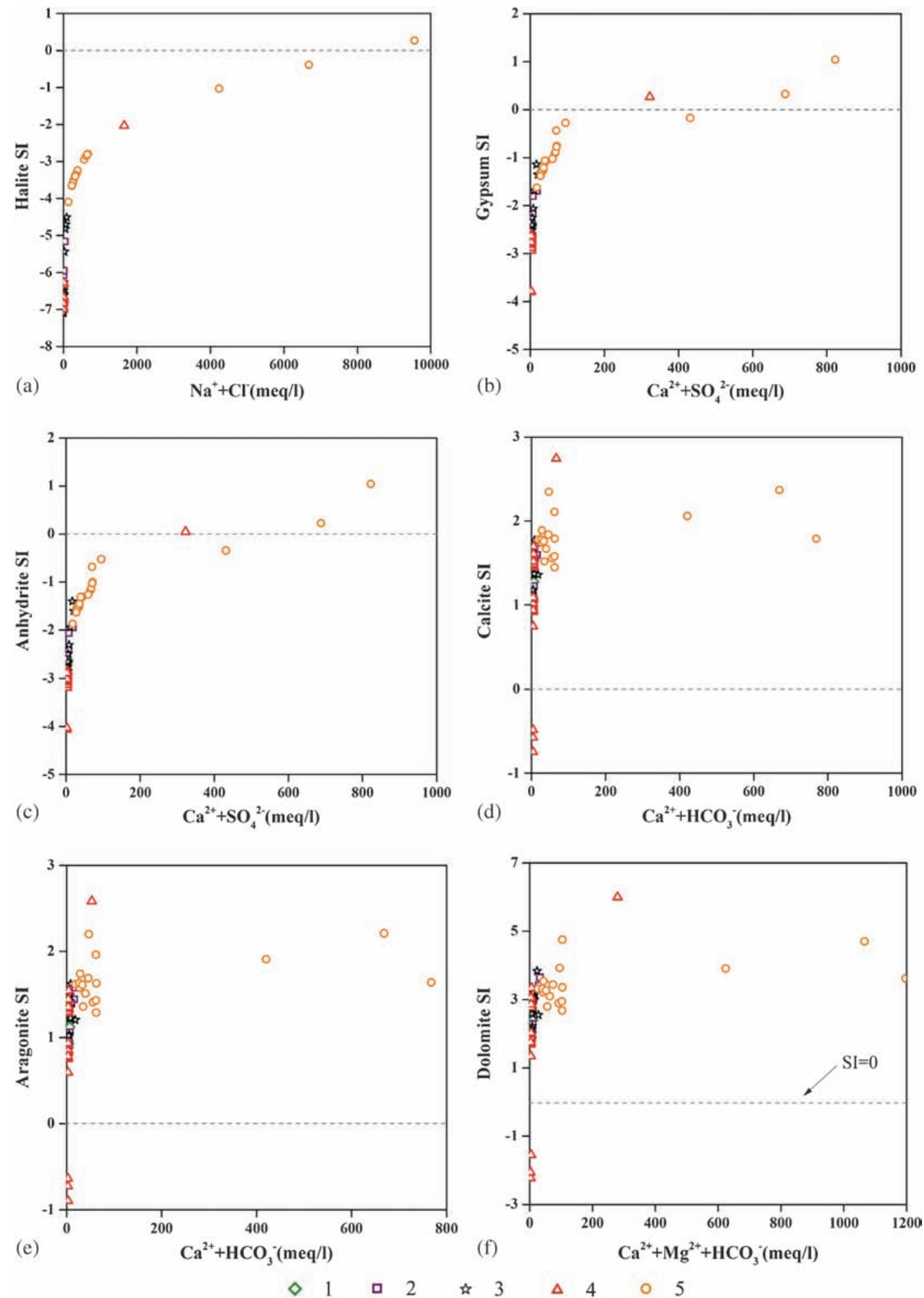

Figure 4. (a) Halite SI vs. $\mathrm{Na}+\mathrm{Cl}$, (b) gypsum SI vs. $\mathrm{Ca}+\mathrm{SO}_{4},(\mathbf{c})$ anhydrite SI vs. $\mathrm{Ca}+\mathrm{SO}_{4}$, (d) calcite $\mathrm{SI}$ vs. Ca+HCO 3 , (e) aragonite SI vs. $\mathrm{Ca}+\mathrm{HCO}_{3}$ and (f) dolomite SI vs. $\mathrm{Ca}+\mathrm{HCO}_{3}+\mathrm{Mg}$ relationships of the analyzed water samples. 1. GW samples in Zone 1, 2. GW samples in Zone 2, 3. GW samples in ZOne 3, 4. GW samples in Zone 4, and 5. GW samples in Zone 5.

\subsubsection{Residence times of groundwater}

Groundwater residence time provides useful information in understanding the circulation and evolution characteristics of groundwater. In the overall study area, both tritium activities and radiocarbon content were observed with a wide range. Tritium activities ranged from $<1$ to $50.3 \mathrm{TU}$, and measured activities of ${ }^{14} \mathrm{C}$ were in the range of 1.70-73.61 pMC. This phenomenon suggested that 
the groundwater age in the study area varied from present to very old. As can be seen in table 1, groundwater in Zone 1 and northwestern Zone 2 were with high tritium activities $\left({ }^{3} \mathrm{H}\right.$ contents of $\geq 1 \mathrm{TU}$ ), indicating recent water recharge after 1952. While those in Zone 3, Zone 4 and Zone 5

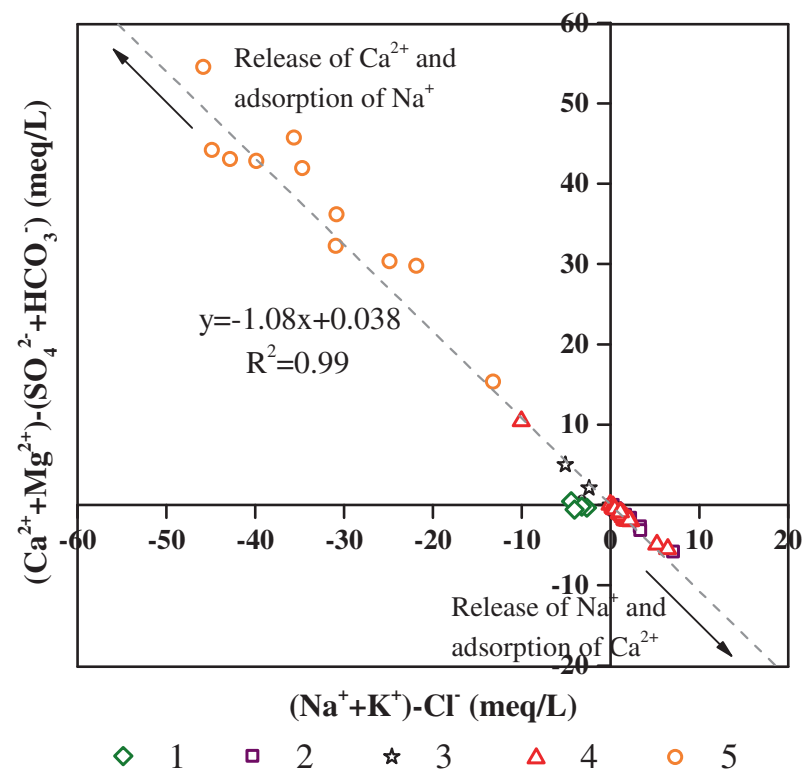

Figure 5. The relationship between $\left(\mathrm{Ca}^{2+}+\mathrm{Mg}^{2+}\right)-\mathrm{SO}_{4}^{2-}+$ $\mathrm{HCO}_{3}^{-}$and $\left(\mathrm{Na}^{+}-\mathrm{Cl}^{-}\right)$in groundwater. 1. GW samples in Zone 1, 2. GW samples in Zone 2, 3. GW samples in Zone 3, 4. GW samples in Zone 4, and 5. GW samples Zone 5.

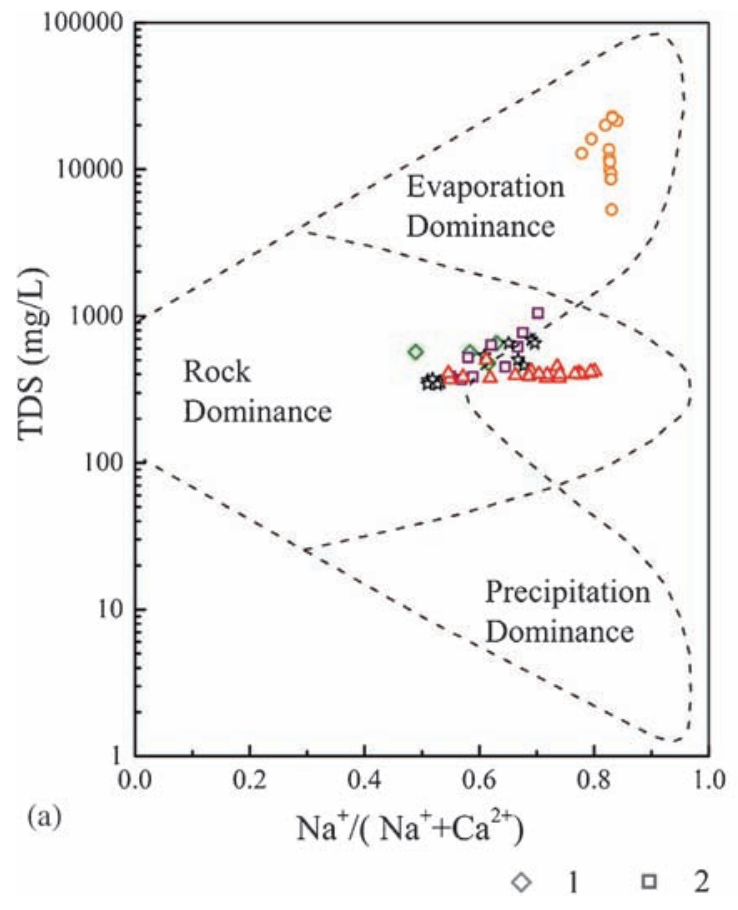

were with low tritium activities $\left({ }^{3} \mathrm{H}\right.$ contents of $<1 \mathrm{TU}$ ), suggesting a pre-1952 age. For the samples with high and low tritium contents, ${ }^{3} \mathrm{H}$ content and ${ }^{14} \mathrm{C}$ activity were used to estimate groundwater age, respectively.

Tritium is a natural radioactive isotope of hydrogen with a half-life of 12.32 years, and its abundance in groundwater is only affected by radioactive decay without the influence of water-rock interaction (Cartwright and Morgenstern 2012). As a result, ${ }^{3} \mathrm{H}$ is an invaluable tool for estimating groundwater age. Determining the historical tritium input is the key to calculate the age of groundwater (Han et al. 2015). Using the methods introduced by IAEA (1992), the historical tritium concentrations in precipitation in the northern slop of the Kunlun Mountains were reconstructed using the available data in the records of Zhang Ye, Hong Kong and Ottawa stations in GNIP, IAEA (figure 8). Considering the difference of hydrogeology condition, different flow models were applied to calculate the groundwater age in different areas. Exponentialpiston flow model (Yurtsever et al. 2001; Liu et al. 2014) was applied to calculate the age of groundwater (G1-G7) sampled from Zone 1, where aquifer was recharged by river seepage and lateral flow. Dispersion model (Yurtsever et al. 2001) was used to estimate the age of groundwater (G18, G19, G21) sampled from the northwestern part of Zone 2 , where there was mixing of younger and older water. The results (figure 9) showed that the age

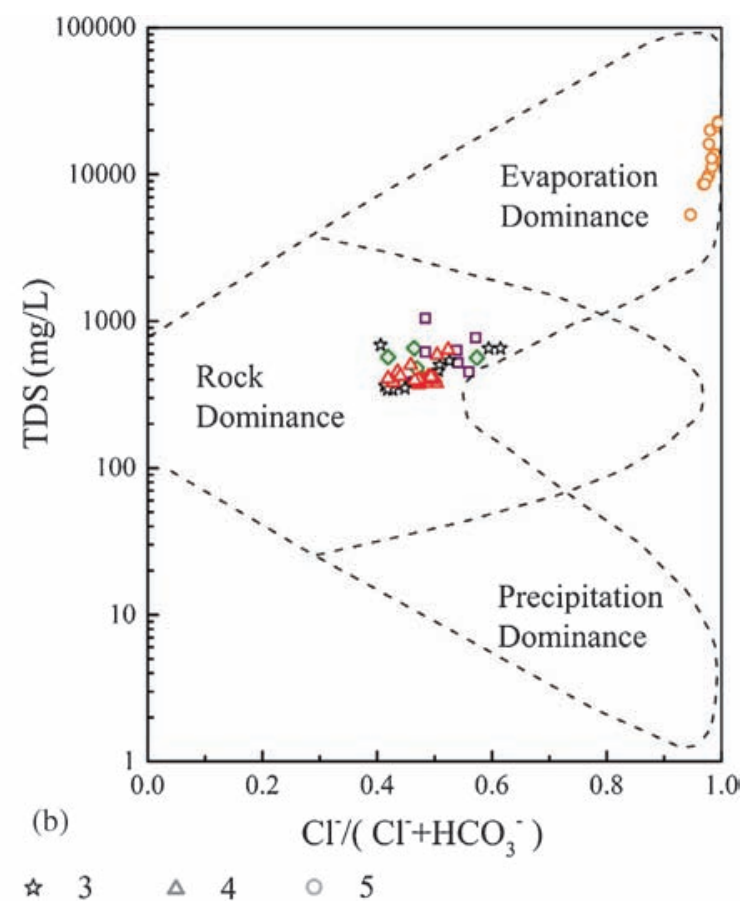

Figure 6. Gibbs diagrams showing the mechanism of groundwater evolution. (a) TDS vs. $\mathrm{Na}^{+} /\left(\mathrm{Na}^{+}+\mathrm{Ca}^{2+}\right)$ and (b) TDS vs. $\mathrm{Cl}^{-} /\left(\mathrm{Cl}^{-}-\mathrm{HCO}^{3-}\right)$. 1. GW samples in Zone 1, 2. GW samples in Zone 2, 3. GW samples in ZOne 3, 4. GW samples in Zone 4, and 5. GW samples in Zone 5. 


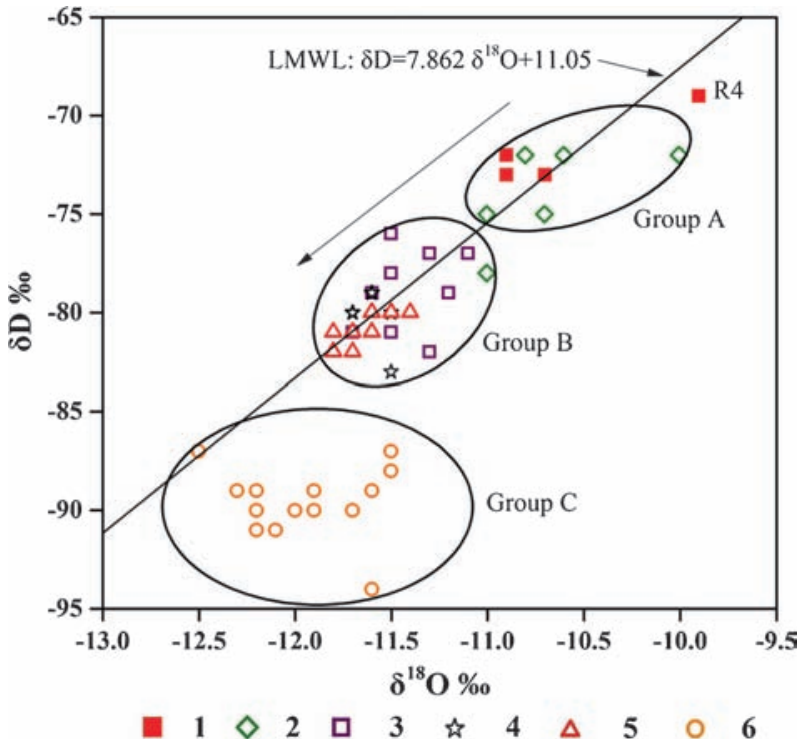

Figure 7. $\delta^{18} \mathrm{O}-\delta \mathrm{D}$ plot of all surface water and groundwater samples. 1. River water samples, 2. GW samples in Zone 1, 3. GW samples in Zone 2, 4. GW samples in Zone 3, 5. GW samples in Zone 4, and 6. GW samples in Zone 5.

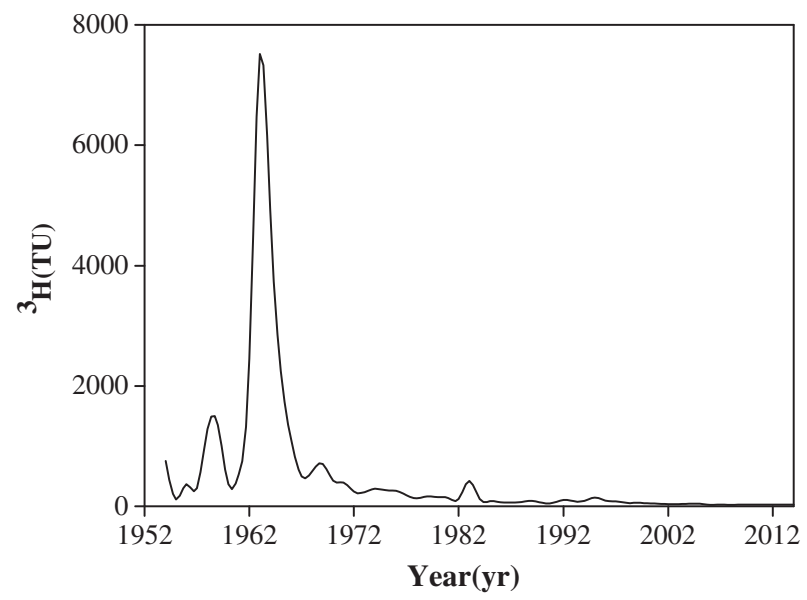

Figure 8. Recovered yearly tritium concentration in precipitation (1954-2014) in the northern slop of the Kunlun Mountains.

of groundwater in the Zone 1 was within $60 \mathrm{a}$, and that in the northwestern part of Zone 2 was in the range of $60-100 \mathrm{a}$.

Different from tritium, ${ }^{14} \mathrm{C}$ concentration is affected by various geochemical processes and hydrodynamic dispersion (Michel 2010). As a result, it cannot represent the residence time since water entering the aquifers and need to be calibrated by certain correction methods. Tamers model (Tamers 1975; Chen et al. 2003) and statistical correction model (Verhagen et al. 1974; Geyh et al. 2000) were conducted in the correction for carbonate dissolution in this study. The groundwater ages calculated by two correction models were almost the same, thus the average values were regarded as the interpretation groundwater age. As shown in figure 9, the age of groundwater in Zone 2 and Zone 3 were in the range of $1-3 \mathrm{ka}$, ranged from 5 to $10 \mathrm{ka}$ in Zone 4, and increased to 17-28 ka in the lower basin (Zone 5).

The distribution of groundwater age also confirmed that groundwater in the study area was recharged under three different conditions, which were described in section 4.2.1. Groundwater in Group A is recharged by modern water with groundwater age younger than $60 \mathrm{a}$, and the relative enriched stable isotope composition is consistent with the modern hot and dry climate in the study area. The recharge period of groundwater in Group $\mathrm{C}$ is in the range of $17-28$ ka before present (B.P.), which is of the last glacial period (Shi et al. 1998; Zhang et al. 2011) with a cold and wet climate, and the water is characterised with obvious depleted stable isotope compositions. The age of groundwater in Group B is less than $10 \mathrm{ka}$, which is after the last glacial period that climate was becoming warmer and drier (Zhang et al. 2011), as a result, groundwater age evolves from old to young with the stable isotope composition getting more enriched gradually.

\subsection{Groundwater flow pattern}

Integrated with groundwater age distribution, hydrochemical characteristics, hydrogeological phenomena and geological structure, the circulation and evolution pattern of groundwater in Nomhon region was established (figure 10).

Groundwater is recharged by lateral flow in the northern edge of Kunlun Mountains and river seepage in the river bed distributing area in Nomhon alluvial fan. Groundwater in the upper alluvial fan has similar hydrochemical characteristic and stable isotope composition compared to the recharge water in the Kunlun Mountains. Groundwater flows from south to north and is blocked by the uplift structure in the front of Nomhon alluvial fan. However, the shallow phreatic water does not expose as springs, but turns its flow direction to the northwest and flows along the south edge of the uplift structure. Eventually, the shallow phreatic water discharges as descending springs and forms Tiangeli River. As shown in figure 9, the age of phreatic groundwater (G18, G19, G21 with the age ranging from 60 to 100 a) in northwestern Nomhon alluvial fan is obviously younger than that (G12 with the age of 1.6 ka B.P.) in northeastern part. This proves that the flow direction of phreatic groundwater turns to northwest. The uplift structure forms a natural groundwater reservoir and stores large amount of groundwater. The groundwater geochemistry in this area is dominantly controlled by water-rock interaction without the effect 


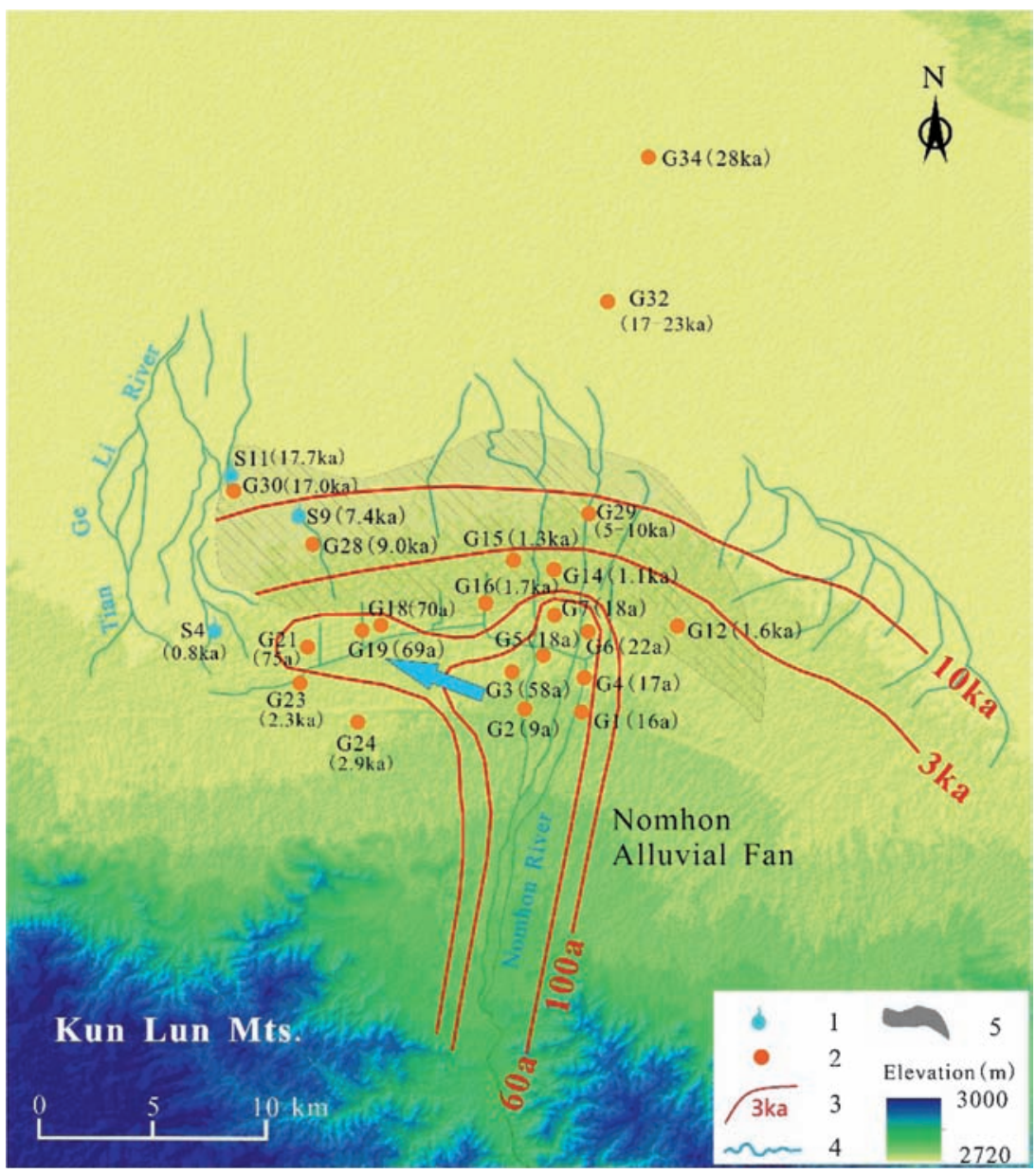

Figure 9. Spatial distribution of groundwater age estimation. 1. Spring sample site, 2. groundwater sample site, 3. groundwater age contour, 4. river, and 5. uplift structure.

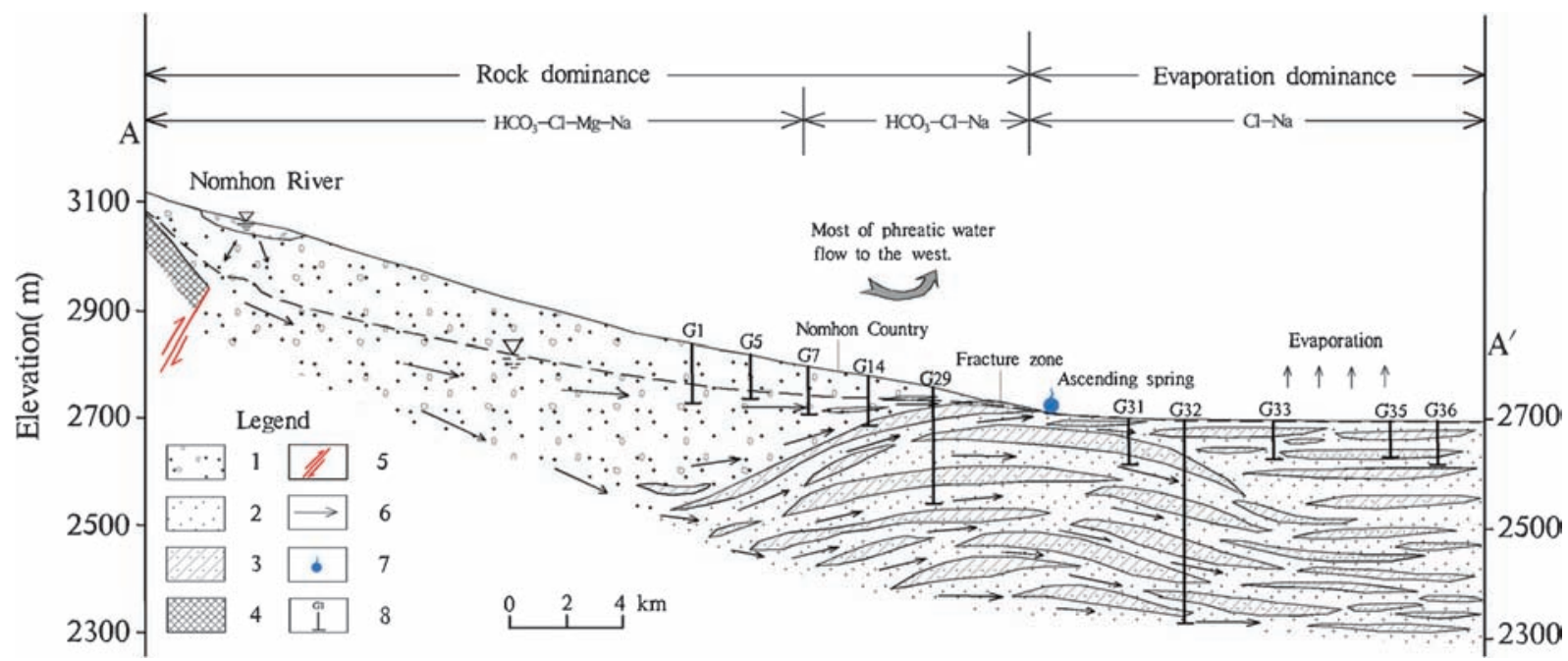

Figure 10. Conceptual model of groundwater flow and evolution. 1. Sandy gravel, 2. sand, 3. clay, 4. bed rock, 5. fault, 6. groundwater flow direction, 7. ascending spring, and 8. borehole and its label.

of evaporation. The quality of groundwater in this area is good and dominated by $\mathrm{HCO}_{3}-\mathrm{Cl}-\mathrm{Mg}-$ $\mathrm{Na}$ water type, which is an ideal area to explore groundwater resource at regional scale.
Because of the block of uplift structure, the flow direction of unconfined groundwater is changed to northwest, only a little part flows to the north through the fracture zone of aquitard. While confined 
groundwater enters in the uplift structure and flows along the bending direction of the uplift structure. Confined water forms high pressure water in the axis of the uplift structure, as a result, most of boreholes are high pressure artesian wells (such as G28, G29 and G30). In addition, a series of ascending springs (such as S6-S15) are formed in the axis of the uplift structure, where aquitard is very thin or non-existent (figure 1). Due to deep circulation, the age of confined groundwater in G29 (5-10 ka B.P.) is obviously older than that in G10 and G11 (1-2 ka B.P.) which are adjacent to G29 with similar depths. The groundwater in the closed flow system of the uplift structure is out of influence of evaporation and groundwater chemistry is dominantly controlled by water-rock interaction. As a result, there lacks transitional groundwater type which is influenced by waterrock interaction and evaporation at the same time during the evolution of groundwater (figure 3). Additionally, absence of $\mathrm{SO}_{4}$ water type in the evolution of groundwater (figure 2) could be attributed to $\mathrm{SO}_{4}^{2-}$ bacterial reduction (R3) under the reducing environment formed by the closed flow system of the uplift structure (Farid et al. 2015). All above makes the salinity of groundwater very slight in this area, and the water type is $\mathrm{HCO}_{3}-\mathrm{Cl}-\mathrm{Na}$. Groundwater should be exploited appropriately in this area.

In the lower basin, groundwater has a slow water alternate rate and is mainly recharged by ancient water of Holocene (17-28 ka B.P.). Groundwater in the lower basin is of Cl-Na type and is mainly controlled by evaporation and crystallization. Groundwater have evolved into saline water and the saturation state of most minerals in groundwater has become saturated or oversaturated (figure 4). After flowing to the near surface and being affected by strong evaporation, groundwater become saltier in the shallow aquifer and even form salt crust on the surface. Due to high concentration of mineral resources, the lower basin is an ideal region to explore salt and brine resources.

\section{Conclusions}

The hydrogeochemistry and isotopic data in Nomhon region have provided useful and helpful insights into groundwater origin, flow path, residence time and hydrochemical evolution. The following are the major conclusions of this study.

Hydrochemical data shows that groundwater evolves from fresh water in the upper alluvial fan to saline water in the lower basin, and the water type varies from $\mathrm{HCO}_{3}-\mathrm{Cl}-\mathrm{Mg}-\mathrm{Na}$ in the alluvial fan to $\mathrm{HCO}_{3}-\mathrm{Cl}-\mathrm{Na}$ in the overflow area, and eventually to $\mathrm{Cl}-\mathrm{Na}$. The $\mathrm{SO}_{4}$ water type is absent in the hydrochemistry evolution. The chemistry evolution of groundwater is controlled by different processes along the flow path. Water-rock interactions, including minerals weathering and dissolution and ions exchange, are the dominant mechanisms controlling groundwater hydrochemistry from the upper alluvial fan to the overflow area. In addition, $\mathrm{SO}_{4}^{2-}$ bacterial reduction is also another important geochemistry process in the overflow area. While the chemistry of groundwater in the lower basin is dominated by evaporation, crystallization and reverse cation exchange.

The stable isotope signatures indicate that groundwater in Nomhon region is of glacier meltwater and meteoric water deriving from Kunlun Mountains. Combining with tritium and radiocarbon results, three different recharge conditions in the study area are identified: Groundwater (Group A) in the river distributing area of Nomhon alluvial fan is recharged by precipitation under modern hot and dry climate condition; Groundwater (Group C) in lower basin is recharged by ancient water under the cold and wet climate condition during the last glacial period; and that (Group B) in front and wings of Nomhon alluvial fan as well as overflow area is recharged after the last glacial period when climate was getting hotter and drier.

Based on the hydrogeochmistry, isotope signature, hydrogeological phenomenon and geological structure, a conceptual groundwater flow pattern affected by uplift structure was proposed. Groundwater flow is blocked by the uplift structure in front of the Nomhon alluvial fan, forming a natural groundwater reservoir with huge quantity and good quality of groundwater. Due to the influence of uplift structure, the flow direction of phreatic groundwater is changed to the northwest and high pressure artesian water is formed in the confined aquifers at the axis of the uplift structure.

This study enhances the understanding on groundwater circulation and hydrochemistry evolution in Qaidam Basin, especially the influence of uplift structure on groundwater flow. The results can also provide reference to get an insight into groundwater circulation and geochemistry controlling mechanisms in semi-arid and arid regions of the world.

\section{Acknowledgements}

This research was supported by the Fundamental Research Funds for the Central Universities (No. 2652016022) and the project ' $1: 50,000$ Hydrogeology Survey in Bayin River \& Tataling River Basin of the Qaidam Basin (DD20160291)' and 'Hydrogeology and Environmental Geology Survey in the circular economy pilot area of the Qaidam 
Basin (1212011220974)' by the China Geological Survey. The authors would like to express their thanks to Xueya Dang at Xi'an Center of Geological Survey, China Geological Survey, for the assistance in the field survey, and Feng Liu and Qichen Hao at Institute of Hydrogeology and Environmental Geology, Chinese Academy of Geological Sciences (IHEG-CAGS). We are grateful to Zongyu Chen at IHEG-CAGS and Xiaomin Gu at China University of Geosciences (Beijing) for the comments on the manuscript.

\section{References}

Appelo C A J and Postma D 2005 Geochemistry groundwater and pollution; 2nd edn, CRC Press, Taylor \& Francis, Boca Raton.

Bouzourra H, Bouhlila R, Elango L, Slama F and Ouslati N 2014 Characterization of mechanisms and processes of groundwater salinization in irrigated coastal area using statistics, GIS, and hydrogeochemical investigations; Environ. Sci. Pollut. Res. 22 2643-2660.

Cartwright I and Morgenstern U 2012 Constraining groundwater recharge and the rate of geochemical processes using tritium and major ion geochemistry: Ovens catchment, southeast Australia; J. Hydrol. 475 137-149.

Chen Z, Qi J, Xu J, Xu J, Ye H and Nan Y 2003 Paleoclimatic interpretation of the past $30 \mathrm{ka}$ from isotopic studies of the deep confined aquifer of the north China plain; Appl. Geochem. 18 997-1009.

Chen Z, Wei W, Liu J, Wang Y and Chen J 2011 Identifying the recharge sources and age of groundwater in the Songnen Plain (northeast China) using environmental isotopes; Hydrogeol. J. 19 163-176.

Dar F A, Perrin J, Ahmed S, Narayana A C and Riotte J 2014 Hydrogeochemical characteristics of Karst Aquifer from a semi-arid region of southern India and impact of rainfall recharge on groundwater chemistry; Arabian J. Geosci. 8 2739-2750.

Farid I, Zouari K, Rigane A and Beji R 2015 Origin of the groundwater salinity and geochemical processes in detrital and carbonate aquifers: Case of Chougafiya basin (central Tunisia); J. Hydrol. 530 508-532.

Fisher R S and Iii W F M 1997 Hydrochemical evolution of sodium-sulfate and sodium-chloride groundwater beneath the northern Chihuahuan Desert, Trans-Pecos, Texas, USA; Hydrogeol. J. 5 4-16.

Geyh M, Amore F D, Darling G, Paces T, Pang Z and Silar J 2000 Environmental isotopes in the hydrological cycle: Principles and applications - groundwater saturated and unsaturated zone; UNESCO \& IAEA, Vienna 4 378-381.

Geyh M A 2005 Dating of old groundwater - History, potential, limits and future. In: Isotopes in the water cycle (eds) Aggarwal P, Gat J and Froehlich KO, Springer, Netherlands, pp. 221-241

Han D, Cao G, Mccallum J and Song X 2015 Residence times of groundwater and nitrate transport in coastal aquifer systems: Daweijia area, northeastern China; Sci. Total Environ. 538 539-554.

Herrera C et al. 2016 Groundwater flow in a closed basin with a saline shallow lake in a volcanic area: Laguna Tuyajto, northern Chilean Altiplano of the Andes; Sci. Total Environ. 541 303-318.

Hoque M A and Burgess W G 2012 14C dating of deep groundwater in the Bengal Aquifer System, Bangladesh: Implications for aquifer anisotropy, recharge sources and sustainability; J. Hydrol. 444-445 209-220.
Huang G, Chen Z, Sun J, Wang J and Hou Q 2016 Groundwater quality in aquifers affected by the anthropogenic and natural processes in an urbanized area, south China; Environ. Forensics 17 107-119.

Jiao J J, Zhang X, Yi L and Kuang X 2015 Increased water storage in the Qaidam Basin, the North Tibet Plateau from GRACE gravity data; PLoS One, doi: 10.1371/journal.pone.0141442.

Jin X, Liu J, Wang S and Xia W 2016 Vegetation dynamics and their response to groundwater and climate variables in Qaidam Basin, China; Int. J. Remote Sens. 37 710-728.

Khalil M M, Tokunaga T and Yousef A F 2015 Insights from stable isotopes and hydrochemistry to the Quaternary groundwater system, south of the Ismailia canal, Egypt; J. Hydrol. 527 555-564.

Li F D, Pan G Y, Tang C Y, Zhang Q Y and Yu J J 2008 Recharge source and hydrogeochemical evolution of shallow groundwater in a complex alluvial fan system, southwest of North China Plain; Environ. Geol. 55 1109-1122.

Liu J, Chen Z, Wen W, Zhang Y, Li Z, Liu F and Guo H 2014 Using chlorofluorocarbons (CFCs) and tritium $(3 \mathrm{H})$ to estimate groundwater age and flow velocity in Hohhot Basin, China; Hydrol. Process. 28 13721382.

Lowenstein T K and Risacher F 2009 Closed basin Brine evolution and the influence of $\mathrm{Ca}-\mathrm{Cl}$ inflow waters: Death Valley and Bristol Dry Lake California, Qaidam Basin, China, and Salar de Atacama, Chile; Aquatic Geochem. 15 71-94.

Lu N and Jin X 2015 Laws of vegetation distribution and evolutionary trend and analysis of the influencing factors in Qaidam Basin; Yellow River 37 94-98 (in Chinese).

Ma H Y, Yin L H, Guo L and Zhang J 2012 Modeling the evaporation line of lake water isotopes in Golmud Drainage Basin, P.R. China; Adv. Mater. Res. 518-523 4186-4193.

Michel R L 2010 Radionuclides as tracers and timers in surface and groundwater; In: Radioactivity in the environment (ed.) Klaus F, Elsevier 16 139-230.

Monjerezi M, Vogt R D, Aagaard P and Saka J D K 2012 The hydro-geochemistry of groundwater resources in an area with prevailing saline groundwater, lower Shire Valley, Malawi; J. African Earth Sci. 68 67-81.

Reddy A G S and Kumar K N 2010 Identification of the hydrogeochemical processes in groundwater using major ion chemistry: A case study of Penna-Chitravathi river basins in southern India; Environ. Monit. Assess. 170 $365-382$.

Redwan M and Moneim A A A 2015 Factors controlling groundwater hydrogeochemistry in the area west of Tahta, Sohag, Upper Egypt; J. African Earth Sci. 118 328-338.

Shi D, Yin X, Sun J and Yin Z 1998 A simulation study on the evolution of groundwater circulation systems in Cenozoic basins of northern China; Acta. Geol. Sin. 72 100-107.

Stadler S, Osenbrück K, Suckow A O, Himmelsbach T and Hötzl H 2010 Groundwater flow regime, recharge and regional-scale solute transport in the semi-arid Kalahari of Botswana derived from isotope hydrology and hydrochemistry; J. Hydrol. 388 291-303.

Tamers M A 1975 Validity of radiocarbon dates on ground water; Geophys. Surv. 2 217-239.

Tan H, Rao W, Chen J, Su Z, Sun X and Liu X 2009 Chemical and isotopic approach to groundwater cycle in western Qaidam Basin, China; Chinese Geogr. Sci. 19 $357-364$.

Tirumalesh K, Shivanna K, Noble J, Narayan K K and Xavier K T 2007 Nuclear techniques to investigate source and origin of groundwater pollutants and their flow path 
at Indian Rare Earths Ltd., Cochin, Kerala; J. Radioanal. Nuclear Chem. 274 307-313.

Utting N, Lauriol B, Mochnacz N, Aeschbach-Hertig W and Clark I 2013 Noble gas and isotope geochemistry in western Canadian Arctic watersheds: Tracing groundwater recharge in permafrost terrain; Hydrogeol. J. 21 79-91.

Van Geldern R, Baier A, Subert H L, Kowol S, Balk L and Barth J A C 2014 Pleistocene paleo-groundwater as a pristine fresh water resource in southern Germany evidence from stable and radiogenic isotopes; Sci. Total Environ. 496 107-115.

Verhagen B T, Mazor E and Sellschop J P F 1974 Radiocarbon and tritium evidence for direct rain recharge to ground waters in the northern Kalahari; Nature 249 643-644.

Voutsis N, Kelepertzis E, Tziritis E and Kelepertsis A 2015 Assessing the hydrogeochemistry of groundwaters in ophiolite areas of Euboea Island, Greece, using multi-variate statistical methods; J. Geochem. Explor. 159 79-92.

Wang H, Mao X and Feng L 2015 Evidence of groundwater degassing in a deep confined aquifer: noble gas concentrations with hydrogen, oxygen and carbon isotope data; Environ. Earth Sci. 74 4439-4451.

Wang P, Yu J, Zhang Y and Liu C 2013 Groundwater recharge and hydrogeochemical evolution in the Ejina Basin, northwest China; J. Hydrol. 476 72-86.

Wang Y 2008 Groundwater resources and environment issues survey and assessment in Qaidam Basin; Geological Publishing House, Beijing (in Chinese).

Wei H Z, Jiang S Y, Tan H B, Zhang W J, Li B K and Yang T L 2014 Boron isotope geochemistry of salt sediments from the Dongtai salt lake in Qaidam Basin: Boron budget and sources; Chem. Geol. 380 74-83.

Yangui H, Zouari K, Trabelsi R and Rozanski K 2011 Recharge mode and mineralization of groundwater in a semi-arid region: Sidi Bouzid plain (central Tunisia); Environ. Earth Sci. 63 969-979.

Ye C, Zheng M, Wang Z, Hao W, Wang J, Lin X and Han J 2015 Hydrochemical characteristics and sources of brines in the Gasikule salt lake, northwest Qaidam Basin, China; Geochem. J. 49 481-494.

$\mathrm{Yu} \mathrm{Y}$ et al. 2013 Identification of key factors governing chemistry in groundwater near the water course recharged by reclaimed water at Miyun County, northern China; J. Environ. Sci. 25 1754-1763.

Yurtsever Y, Zuber A, Maloszewski P, Campana M E, Harrington G A, Tezcan L and Konikow L F 2001 Environmental isotopes in the hydrological cycle: Principles and applications; Modelling UNESCO $\& 5$ IAEA Vienna 6 500-502.

Zhai Y, Wang J, Huan H, Zhou J and Wei W 2013 Characterizing the groundwater renewability and evolution of the strongly exploited aquifers of the North China Plain by major ions and environmental tracers; J. Radioanal. Nuclear Chem. 296 1263-1274.

Zhang M, Chen Y, Yin S, Zhang J, Li C and Liu G 2011 Sedimental features and paleo-environment reconstruction of the slope deposit at Xiaogangou of the Golmud River; Arid Land Geography 34 890-903 (in Chinese).

Zhang W, Tan H, Zhang Y, Wei H and Dong T 2015 Boron geochemistry from some typical Tibetan hydrothermal systems: Origin and isotopic fractionation; Appl. Geochem. 63 436-445. 